\title{
Distribution Equilibria of Amphoteric 8-Quinolinol between 1-Alkyl-3-methylimidazolium Bis(trifluoromethanesulfonyl)imide and Aqueous Phases and Their Effect on Ionic Liquid Chelate Extraction Behavior of Iron(III)
}

\author{
Ayano Eguchi, Kotaro Morita, and Naoki HiraYama ${ }^{\dagger}$ \\ Department of Chemistry, Faculty of Science, Toho University, 2-2-1 Miyama, Funabashi 274-8510, Japan
}

\begin{abstract}
The distribution behavior of amphoteric 8-quinolinol (HQ) between ionic liquid (IL) phase and aqueous phase and ionic liquid chelate extraction behavior of iron(III) with HQ were investigated using four 1-alkyl-3-methylimidazolium bis(trifluoromethanesulfonyl)imide $\left(\mathrm{C}_{n} \operatorname{mimTf}_{2} \mathrm{~N}, n=2,4,6\right.$ and 8) ILs. Not only neutral HQ but also cationic $\mathrm{H}_{2} \mathrm{Q}^{+}$were distributed into the IL phase, and the latter distribution based on cation-exchange with $\mathrm{C}_{\mathrm{n}} \mathrm{mim}^{+}$was pronounced in the use of IL having a less-hydrophobic cation, such as $\mathrm{C}_{2} \mathrm{mim}^{+}$. In the IL chelate extraction of iron(III), the extractability increased with the increase in the hydrophobicity of IL as the extraction phase. Nevertheless, the determined equilibrium constants for the extraction as the neutral complex $\mathrm{FeQ}_{3}$ were similar to one another. The difference in the extractability among the ILs was due to the difference in the distribution of $\mathrm{H}_{2} \mathrm{Q}^{+}$into the extraction phase. In addition, the cationic coordinatively-unsaturated complex $\mathrm{FeQ}_{2}{ }^{+}$was also extracted in use of less-hydrophobic $\mathrm{C}_{2}$ mimTf $_{2} \mathrm{~N}$.
\end{abstract}

Keywords Ionic liquids, 8-quinolinol, cation-exchange, chelate extraction, iron(III)

(Received September 3, 2017; Accepted October 13, 2017; Published December 10, 2017)

\section{Introduction}

Ionic liquids (ILs) are generally defined as "liquids composed entirely of ions that are fluid around or below $100^{\circ} \mathrm{C},{ }^{1}$, which have attracted much attention as novel liquid media. ILs are also used in analytical chemistry, including electroanalytical chemistry $^{2,3}$ and separation chemistry. ${ }^{4-7}$

Solvent extraction of metal cations is a separation technique using large amounts of hydrophobic organic solvents for the extraction phase materials. Therefore, possible use of hydrophobic ILs, including 1-alkyl-3-methylimidazolium hexafluorophosphate $\left(\mathrm{C}_{\mathrm{n}} \mathrm{mimPF}_{6}\right)$ and 1-alkyl-3-methylimidazolium bis(trifluoromethanesulfonyl)imide $\left(\mathrm{C}_{\mathrm{n}} \operatorname{mimTf}_{2} \mathrm{~N}\right)$, as alternatives to the organic solvents has been energetically investigated. ${ }^{8-19}$ Among several approaches, ionic liquid chelate extraction using Brønsted acidic chelators as extraction reagents ${ }^{20,21}$ is interesting because a change in the aqueousphase $\mathrm{pH}$ results in changing the extraction performance.

In conventional chelate extraction process using organic solvents, metal cations are generally extracted as neutral complexes. Although hydrophobic ILs have relatively high polarity, ${ }^{22}$ many kinds of metal cations are extracted as neutral complexes in IL chelate extraction as well. However, hydrophobic ILs also have ion-exchange abilities ${ }^{23}$ and, therefore, charged complexes may be extracted. For example, several divalent transition metals $\mathrm{s}^{20,24}$ and trivalent lanthanoids ${ }^{25}$ were extracted into ILs with 2-thenoyltrifluoroacetone (Htta) as monoanionic complexes. Moreover, the ion-exchange abilities may affect the distribution behavior of extraction reagents between the two phases. Actually, anionic tta- showed a quite high affinity to the IL phase. ${ }^{26}$

8-Hydroxyquinoline (HQ) is a well-known bidentate extraction reagent. Although there are many papers on use of HQ in IL chelate extraction, ${ }^{27-37}$ the distribution behavior of HQ between IL and aqueous phases has not been investigated. HQ is an amphoteric compound, which has the following two acid-base equilibria:

$$
\begin{aligned}
& \mathrm{H}_{2} \mathrm{Q}^{+} \rightleftharpoons \mathrm{H}^{+}+\mathrm{HQ}, \\
& \mathrm{HQ} \rightleftharpoons \mathrm{H}^{+}+\mathrm{Q}^{-} .
\end{aligned}
$$

The formation of cationic $\mathrm{H}_{2} \mathrm{Q}^{+}$in the aqueous phase causes suppression of the chelate extraction as a side reaction; also, the distribution of the cationic $\mathrm{H}_{2} \mathrm{Q}^{+}$into the IL phase can result in a further enhancement of the suppression. Namely, evaluating the distribution behavior of HQ between the phases is very important for investigating the IL chelate extraction behavior of metals with HQ, particularly in the acidic condition. In this study, the distribution behavior of HQ into several 1-alkyl-3methylimidazolium bis(trifluoromethanesulfonyl)imide $\left(\mathrm{C}_{\mathrm{n}} \operatorname{mimTf}_{2} \mathrm{~N}\right)$ ILs was evaluated, and its effect on the IL chelate extraction behavior of iron(III) was investigated.

$\dagger$ To whom correspondence should be addressed.

E-mail: hirayama@sci.toho-u.ac.jp 


\section{Experimental}

\section{Chemicals}

Four ILs [1-ethyl-3-methylimidazolium bis(trifluoromethanesulfonyl)imide $\left(\mathrm{C}_{2} \operatorname{mimTf}_{2} \mathrm{~N}\right), \quad$ 1-butyl-3-methylimidazolium bis(trifluoromethanesulfonyl)imide $\quad\left(\mathrm{C}_{4} \operatorname{mimTf}_{2} \mathrm{~N}\right)$, 1-hexyl-3methylimidazolium bis(trifluoromethanesulfonyl)imide $\left(\mathrm{C}_{6} \mathrm{mim}-\right.$ $\mathrm{Tf}_{2} \mathrm{~N}$ ) and 1-methyl-3-octylimidazolium bis(trifluoromethanesulfonyl)imide $\left.\left(\mathrm{C}_{8} \operatorname{mimTf}_{2} \mathrm{~N}\right)\right]$ were synthesized according to a reported procedure..$^{38,39}$ The extraction reagent $\mathrm{HQ}$ was purchased from Wako Pure Chemical Industries (Osaka, Japan). Other chemicals and solvents included reagent-grade materials, which were used without further purification. High-purity water was produced with a Millipore Direct-Q water-purification system.

\section{Apparatus}

The absorption spectra of solutions were recorded on a JASCO V-630 UV/visible spectrophotometer using $1 \mathrm{~cm}$ matched quartz cells. A Thermo Fischer Scientific iCE3000 flame atomic absorption spectrophotometer was used for determining of the concentration of a metal in the aqueous phase. A Horiba Model F-52 pH meter equipped with a Horiba 9680S-10D combined glass electrode was used to determine the $\mathrm{pH}$ values.

\section{Distribution of $H Q$}

The distribution of the extraction reagent between $\mathrm{C}_{\mathrm{n}} \operatorname{mimTf}_{2} \mathrm{~N}$ and aqueous phases was measured as follows. In a centrifuge tube, an aliquot $\left(8.0 \mathrm{~cm}^{3}\right)$ of aqueous solution containing $5.0 \times 10^{-4} \mathrm{~mol} \mathrm{dm}^{-3} \mathrm{HQ}, 1 \times 10^{-1} \mathrm{~mol} \mathrm{dm}^{-3}$ sodium chloride and $1 \times 10^{-2} \mathrm{~mol} \mathrm{dm}^{-3}$ of buffer [chloroacetic acid, acetic acid, 2-( $N$-morpholino)ethanesulfonic acid, 3-( $N$-morpholino)propanesulfonic acid, $N$-tris(hydroxymethyl)methyl-3-aminopropanesulfonic acid or $N$-cyclohexyl-2-aminoethanesulfonic acid] or suitable concentration of hydrochloric acid or sodium hydroxide was shaken with $1.0 \mathrm{~cm}^{3}$ of $\mathrm{C}_{\mathrm{n}} \operatorname{mimTf}_{2} \mathrm{~N}$ at $25 \pm 1^{\circ} \mathrm{C}$ for $30 \mathrm{~min}$ to be equilibrated. After the two phases were separated by centrifugation, the $\mathrm{pH}$ in the aqueous phase was determined and the measured $\mathrm{pH}$ was used as the equilibrated $\mathrm{pH}$. The equilibrated aqueous phase was diluted by using $1 \mathrm{~mol} \mathrm{dm}^{-3}$ $\mathrm{NaOH}$, after which absorbance of the diluted solution at $353.5 \mathrm{~nm}$ (maximum absorption wavelength for $\mathrm{Q}^{-}$) was measured to determine the HQ concentration in the aqueous phase. Its concentration in the $\mathrm{C}_{\mathrm{n}} \operatorname{mimTf}_{2} \mathrm{~N}$ phase was calculated from the mass balance, and the distribution ratio of $\mathrm{HQ}\left(D_{\mathrm{HQ}}\right)$ was calculated using these values. In addition, the distribution of $\mathrm{NaCl}$ and the buffer components into the IL phase was regarded as being negligible.

\section{Distribution of $\mathrm{Fe}(\mathrm{III})$}

The distribution of $\mathrm{Fe}(\mathrm{III})$ between $\mathrm{C}_{\mathrm{n}} \operatorname{mimTf}_{2} \mathrm{~N}$ and aqueous phases in the IL chelate extraction system was measured as follows. In a centrifuge tube, an aliquot $\left(1.0 \mathrm{~cm}^{3}\right)$ of a $\mathrm{C}_{\mathrm{n}} \operatorname{mimTf}_{2} \mathrm{~N}$ phase containing $1.0 \times 10^{-2} \mathrm{~mol} \mathrm{dm}^{-3}$ of HQ and $5.0 \mathrm{~cm}^{3}$ of an aqueous phase containing $3.4 \times 10^{-5} \mathrm{~mol} \mathrm{dm}^{-3}$ $\left(2.0 \mathrm{mg} \mathrm{dm}^{-3}\right)$ of $\mathrm{Fe}(\mathrm{III}), 1.0 \times 10^{-1} \mathrm{~mol} \mathrm{dm} \mathrm{dm}^{-3}$ of potassium nitrate and $1.0 \times 10^{-2} \mathrm{~mol} \mathrm{dm}^{-3}$ of buffer (chloroacetic acid or acetic acid) were shaken mechanically at $25 \pm 1{ }^{\circ} \mathrm{C}$ for $30 \mathrm{~min}$ to be equilibrated. After the two phases were separated by centrifugation, the $\mathrm{pH}$ in the aqueous phase was determined. The Fe concentration in the aqueous phase and that in the organic phase (after back-extraction into $1.0 \mathrm{~mol} \mathrm{dm}^{-3}$ nitric acid) were determined by flame AAS. The extractability $(\% E)$ and the distribution ratio $(D)$ of $\mathrm{Fe}$ were calculated with using

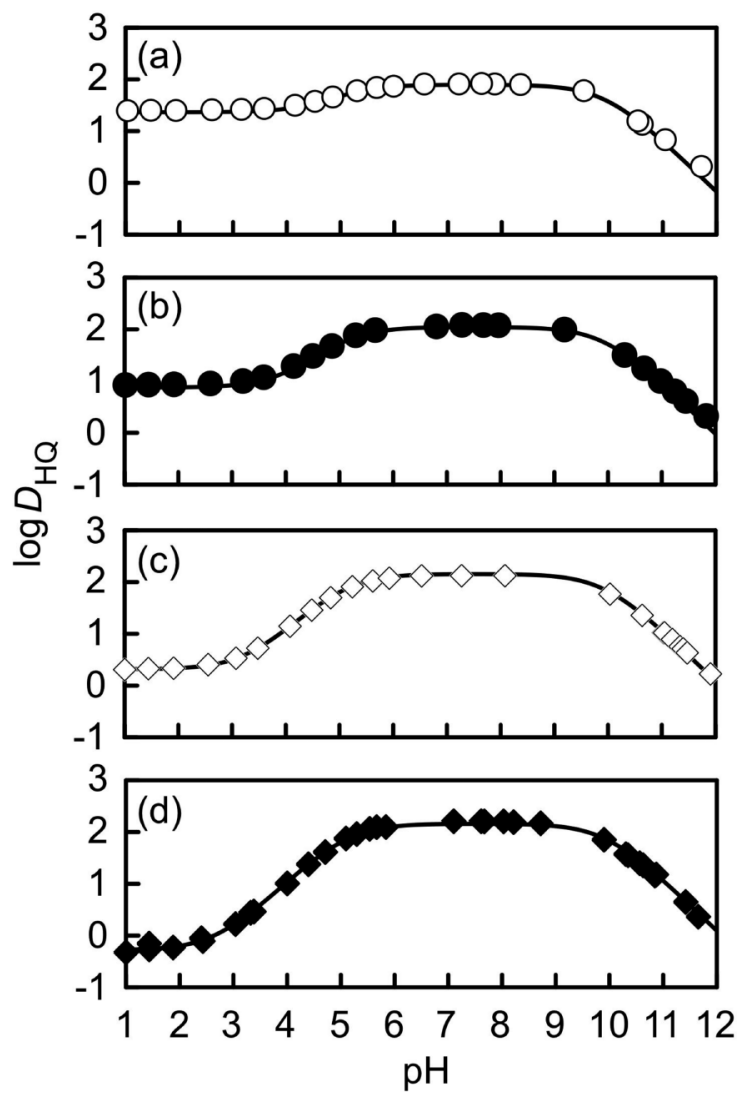

Fig. 1 Relationship between logarithmic the distribution ratio of HQ $\left(\log D_{\mathrm{HQ}}\right)$ and the aqueous phase $\mathrm{pH}$. The solid curves were obtained by a non-linear least squares fitting. Extraction phase: (a) $\mathrm{C}_{2} \operatorname{mimTf}_{2} \mathrm{~N}$; (b) $\mathrm{C}_{4} \operatorname{mimTf}{ }_{2} \mathrm{~N}$; (c) $\mathrm{C}_{6} \operatorname{mimTf}_{2} \mathrm{~N}$; (d) $\mathrm{C}_{8} \operatorname{mimTf}_{2} \mathrm{~N}$.

these values. In addition, distribution of $\mathrm{KNO}_{3}$ and the buffer components into the IL phase was regarded as being negligible.

\section{Results and Discussion}

\section{Distribution equilibria of $H Q$}

The $\mathrm{pH}$ dependency in the distribution of HQ between IL and aqueous phases was investigated at the $\mathrm{pH}$ range of $1-12$ with using the four ILs. Figure 1 shows the relationship between $\log D_{\mathrm{HQ}}$ and the aqueous phase $\mathrm{pH}$ for the four systems. In all systems, $\log D_{\mathrm{HQ}}$ showed a constant value not only at neutral $\mathrm{pH}$ (ca. $6-8)$ but also at acidic pH (ca. $1-2)$. This result indicated that not only neutral HQ but also cationic $\mathrm{H}_{2} \mathrm{Q}^{+}$distribute in the IL phases. In addition, the distribution of anionic $\mathrm{Q}^{-}$was negligibly low in this study.

The distribution equilibrium of neutral HQ is

$$
\mathrm{HQ} \rightleftharpoons \mathrm{HQ}_{\mathrm{IL}},
$$

where subscript IL shows the IL phase, and the distribution constant, $K_{\mathrm{D}, \mathrm{HQ}}$ is defined as

$$
K_{\mathrm{D}, \mathrm{HQ}}=[\mathrm{HQ}]_{\mathrm{II}} /[\mathrm{HQ}] .
$$

The distribution equilibrium of acidic $\mathrm{H}_{2} \mathrm{Q}^{+}$, on the contrary, is based on the cation-exchange reaction shown as

$$
\mathrm{H}_{2} \mathrm{Q}^{+}+\mathrm{C}_{\mathrm{n}} \mathrm{mim}^{+}{ }_{\mathrm{IL}} \rightleftharpoons \mathrm{H}_{2} \mathrm{Q}^{+}{ }_{\mathrm{IL}}+\mathrm{C}_{\mathrm{n}} \mathrm{mim}^{+}
$$


Table 1 Obtained $\log K_{\mathrm{D}, \mathrm{HQ}}, \log K_{\mathrm{D}, \mathrm{H} 2 \mathrm{Q}+}^{\prime}$ and $\log K_{\mathrm{D}, \mathrm{H} 2 \mathrm{Q}+}$ values

\begin{tabular}{ccrcc}
\hline $\begin{array}{c}\text { Extraction } \\
\text { solvent }\end{array}$ & $\log K_{\mathrm{D}, \mathrm{HQ}}$ & $\log K_{\mathrm{D}, \mathrm{H} 2 \mathrm{Q}+}^{\prime}$ & $K_{\mathrm{SP}} / \mathrm{mol}^{2} \mathrm{dm}^{-640}$ & $\log K_{\mathrm{D}, \mathrm{H} 2 \mathrm{Q}+}$ \\
\hline $\mathrm{C}_{2} \operatorname{mimTf}_{2} \mathrm{~N}$ & $1.90 \pm 0.01$ & $1.36 \pm 0.01$ & $2.17 \times 10^{-3}$ & 0.03 \\
$\mathrm{C}_{4} \operatorname{mimTf}_{2} \mathrm{~N}$ & $2.05 \pm 0.01$ & $0.87 \pm 0.01$ & $2.91 \times 10^{-4}$ & -0.89 \\
$\mathrm{C}_{6} \operatorname{mimTf}_{2} \mathrm{~N}$ & $2.16 \pm 0.01$ & $0.32 \pm 0.01$ & $2.82 \times 10^{-5}$ & -1.96 \\
$\mathrm{C}_{8} \operatorname{mimTf}_{2} \mathrm{~N}$ & $2.16 \pm 0.01$ & $-0.28 \pm 0.02$ & $3.49 \times 10^{-6}$ & -3.01 \\
\hline
\end{tabular}

Also the equilibrium constant, $K_{\mathrm{D}, \mathrm{H} 2 \mathrm{Q}+}$, can be defined as

$$
K_{\mathrm{D}, \mathrm{H} 2 \mathrm{Q}+}=\left[\mathrm{H}_{2} \mathrm{Q}^{+}\right]_{\mathrm{IL}}\left[\mathrm{C}_{\mathrm{n}} \mathrm{mim}^{+}\right] /\left[\mathrm{H}_{2} \mathrm{Q}^{+}\right] .
$$

(The activity of $\mathrm{C}_{\mathrm{n}} \mathrm{mim}^{+}$in the IL phase is defined as unity.) Since the total amount of HQ is sufficiently small compared with $\mathrm{C}_{\mathrm{n}} \mathrm{mim}^{+},\left[\mathrm{C}_{\mathrm{n}} \mathrm{mim}^{+}\right]$can be approximately calculated from the solubility product of $\mathrm{C}_{\mathrm{n}} \operatorname{mimTf}_{2} \mathrm{~N}\left(K_{\mathrm{SP}}\right)$ as follows:

$$
\left[\mathrm{C}_{\mathrm{n}} \mathrm{mim}^{+}\right]=\left[\mathrm{Tf}_{2} \mathrm{~N}^{-}\right]=K_{\mathrm{SP}^{1 / 2}}
$$

and the following apparent distribution constant, $K_{\mathrm{D}, \mathrm{H} 2 \mathrm{Q}+}^{\prime}$, can be defined:

$$
\begin{aligned}
& K_{\mathrm{D}, \mathrm{H} 2 \mathrm{Q}+}^{\prime}=\left[\mathrm{H}_{2} \mathrm{Q}^{+}\right]_{\mathrm{IL}} /\left[\mathrm{H}_{2} \mathrm{Q}^{+}\right] \\
& \quad=K_{\mathrm{D}, \mathrm{H} 2 \mathrm{Q}+} /\left[\mathrm{C}_{\mathrm{n}} \mathrm{mim}^{+}\right]=K_{\mathrm{D}, \mathrm{H} 2 \mathrm{Q}+} K_{\mathrm{SP}^{-1 / 2}} .
\end{aligned}
$$

When using $K_{\mathrm{D}, \mathrm{HQ}}$ and $K_{\mathrm{D}, \mathrm{H} 2 \mathrm{Q}+}^{\prime}, D_{\mathrm{HQ}}$ is presented as a function of $\left[\mathrm{H}^{+}\right]$, as follows:

$$
\begin{aligned}
& D_{\mathrm{HQ}}=\left(\left[\mathrm{H}_{2} \mathrm{Q}^{+}\right]_{\mathrm{IL}}+[\mathrm{HQ}]_{\mathrm{IL}}\right) /\left(\left[\mathrm{H}_{2} \mathrm{Q}^{+}\right]+[\mathrm{HQ}]+\left[\mathrm{Q}^{-}\right]\right) \\
& \quad=\left(K_{\mathrm{D}, \mathrm{H} 2 \mathrm{Q}+}^{\prime}\left[\mathrm{H}^{+}\right] K_{\mathrm{a} 1}^{-1}+K_{\mathrm{D}, \mathrm{HQ}}\right) /\left(\left[\mathrm{H}^{+}\right] K_{\mathrm{a} 1}^{-1}+1+K_{\mathrm{a} 2}\left[\mathrm{H}^{+}\right]^{-1}\right),(9)
\end{aligned}
$$

where $K_{\mathrm{a} 1}$ and $K_{\mathrm{a} 2}$ are the acid dissociation constants of HQ for Eqs. (1) and (2), respectively.

Based on Eq. (9), the values of $\log K_{\mathrm{D}, \mathrm{HQ}}$ and $\log K_{\mathrm{D}, \mathrm{H} 2 \mathrm{Q}+}^{\prime}$ were calculated using a non-linear least-squares fitting to Fig. 1 . The obtained values are summarized in Table 1 with $\log K_{\mathrm{D}, \mathrm{H} 2 \mathrm{Q}+}$ calculated with using $K_{\mathrm{SP}}$ values. ${ }^{40}$ In consideration with dissolution equilibrium for $\mathrm{C}_{\mathrm{n}} \operatorname{mimTf}_{2} \mathrm{~N}$, possible deviation of actual $\left[\mathrm{C}_{\mathrm{n}} \mathrm{mim}^{+}\right]$from $K_{\mathrm{SP}}{ }^{1 / 2}$ was numerically estimated as being within $1 \%$ (0.005 logarithmic unit), and it was confirmed that the approximation shown in Eq. (7) is appropriate in this case. In addition, the $\mathrm{p} K_{\mathrm{a} 1}$ and $\mathrm{p} K_{\mathrm{a} 2}$ values for $\mathrm{HQ}$ were also calculated from the data as $5.12 \pm 0.04$ and $9.93 \pm 0.07$, respectively. These values are close to ones reported previously (5.00 and 9.66, respectively ${ }^{41}$ ).

Although similar $\log K_{\mathrm{D}, \mathrm{HQ}}$ values were obtained for all systems, more hydrophobic IL showed a marginally larger $\log K_{\mathrm{D}, \mathrm{HQ}}$ value. This tendency is similar to the case of Htta. ${ }^{26}$ On the contrary, the $\log K_{\mathrm{D}, \mathrm{H} 2 \mathrm{Q}^{+}}^{\prime}\left(\right.$ and $\left.\log K_{\mathrm{D}, \mathrm{H} 2 \mathrm{Q}+}\right)$ values were quite different between the systems. Being concrete, the order of $\log K_{\mathrm{D}, \mathrm{H} 2 \mathrm{Q}+}^{\prime}$ value was $\mathrm{C}_{2} \operatorname{mimTf}_{2} \mathrm{~N}>\mathrm{C}_{4} \operatorname{mimTf}_{2} \mathrm{~N}>\mathrm{C}_{6} \operatorname{mimTf}_{2} \mathrm{~N}>$ $\mathrm{C}_{8} \operatorname{mimTf}_{2} \mathrm{~N}$ and IL having a more hydrophobic cation showed a lower $\log K_{\mathrm{D}, \mathrm{H} 2 \mathrm{Q}+}^{\prime}$ value. This order is the same as the distribution of various cations, including 1-ethylpyridinium. ${ }^{42}$

\section{Extraction of $\mathrm{Fe}(\mathrm{III})$ with $\mathrm{HQ}$}

For the four IL extraction systems, the $\% E$ values of $\mathrm{Fe}(\mathrm{III})$ were plotted as a function of the aqueous phase $\mathrm{pH}$. The results are shown in Fig. 2. For a comparison, those using conventional organic solvents, such as toluene and chloroform, are also plotted in the figure. Interestingly, there is an obvious difference in the extractability among the four systems. The extractability

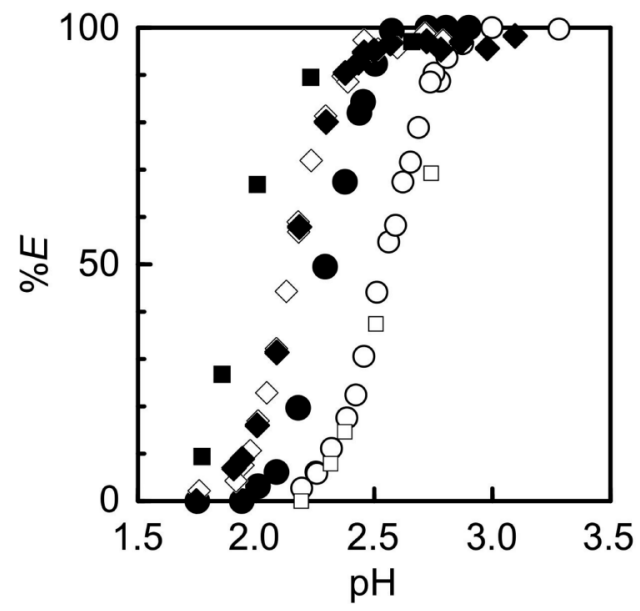

Fig. 2 Plots of the extractability of $\mathrm{Fe}(\mathrm{III})(\% E)$ as a function of the aqueous phase $\mathrm{pH}$. Initial HQ concentration in the extraction phase was $1.0 \times 10^{-2} \mathrm{~mol} \mathrm{dm}^{-3}$. Extraction phase: $\bigcirc, \mathrm{C}_{2} \operatorname{mimTf}_{2} \mathrm{~N}$; $\mathrm{C}_{4} \operatorname{mimTf}_{2} \mathrm{~N} ; \diamond, \mathrm{C}_{6} \operatorname{mimTf}_{2} \mathrm{~N} ; \diamond, \mathrm{C}_{8} \operatorname{mimTf}_{2} \mathrm{~N} ; \square$; toluene; chloroform.

order was (chloroform $>$ ) $\mathrm{C}_{8} \operatorname{mimTf}_{2} \mathrm{~N} \approx \mathrm{C}_{6} \operatorname{mimTf}_{2} \mathrm{~N}>$ $\mathrm{C}_{4} \operatorname{mimTf}_{2} \mathrm{~N}>\mathrm{C}_{2} \operatorname{mimTf}_{2} \mathrm{~N}(\approx$ toluene $)$.

In the chelate extraction of $\mathrm{Fe}(\mathrm{III})$ with $\mathrm{HQ}$ into a conventional organic solvent, $\mathrm{Fe}(\mathrm{III})$ is generally extracted as neutral complex $\mathrm{FeQ}_{3}$. In that into an IL, however, not only neutral $\mathrm{FeQ}_{3}$ but also cationic complex such as $\mathrm{FeQ}_{2}{ }^{+}$may be extracted as follows:

$$
\begin{aligned}
& \mathrm{Fe}^{3+}+3 \mathrm{HQ}_{\mathrm{IL}} \rightleftharpoons \mathrm{FeQ}_{3 \mathrm{IL}}+3 \mathrm{H}^{+}, \\
& \mathrm{Fe}^{3+}+2 \mathrm{HQ}_{\mathrm{IL}}+\mathrm{C}_{\mathrm{n}} \mathrm{mim}^{+}{ }_{\mathrm{IL}} \rightleftharpoons \mathrm{FeQ}_{2}{ }^{+} \mathrm{IL}+2 \mathrm{H}^{+}+\mathrm{C}_{\mathrm{n}} \mathrm{mim}^{+} .
\end{aligned}
$$

Also, the respective extraction constants are defined as follows:

$$
\begin{aligned}
& K_{\mathrm{ex}, \mathrm{FeQ} 3}=\left[\mathrm{FeQ}_{3}\right]_{\mathrm{IL}}\left[\mathrm{H}^{+}\right]^{3 /} /\left[\mathrm{Fe}^{3+}\right][\mathrm{HQ}]_{\mathrm{IL}}{ }^{3}, \\
& K_{\mathrm{ex}, \mathrm{FeQ} 2+}=\left[\mathrm{FeQ}_{2}{ }^{+}\right]_{\mathrm{IL}}\left[\mathrm{H}^{+}\right]^{2}\left[\mathrm{C}_{\mathrm{n}} \mathrm{mim}^{+}\right] /\left[\mathrm{Fe}^{3+}\right][\mathrm{HQ}]_{\mathrm{IL}}{ }^{2} .
\end{aligned}
$$

These constants can be represented as

$$
\begin{aligned}
& K_{\mathrm{ex}, \mathrm{FeQ} 3}=K_{\mathrm{D}, \mathrm{HQ}}{ }^{-3} K_{\mathrm{a2} 2}^{3} \beta_{\mathrm{FeQ} 3} K_{\mathrm{D}, \mathrm{FeQ} 3}, \\
& K_{\mathrm{ex}, \mathrm{FeQ} 2+}=K_{\mathrm{D}, \mathrm{HQ}}{ }^{-2} K_{\mathrm{a} 2}^{2} \beta_{\mathrm{FeQ} 2+} K_{\mathrm{D}, \mathrm{FeQ} 2+},
\end{aligned}
$$

where stability constants, $\beta_{\mathrm{FeQ} 3}$ and $\beta_{\mathrm{FeQ} 2+}$, are respectively defined as

$$
\begin{aligned}
& \beta_{\mathrm{FeQ} 3}=\left[\mathrm{FeQ}_{3}\right] /\left[\mathrm{Fe}^{3+}\right]\left[\mathrm{Q}^{-}\right]^{3}, \\
& \beta_{\mathrm{FeQ} 2+}=\left[\mathrm{FeQ}_{2}^{+}\right] /\left[\mathrm{Fe}^{3+}\right]\left[\mathrm{Q}^{-}\right]^{2},
\end{aligned}
$$

and the distribution constants, $K_{\mathrm{D}, \mathrm{FeQ} 3}$ and $K_{\mathrm{D}, \mathrm{FeQ} 2+}$, are respectively defined as

$$
\begin{aligned}
K_{\mathrm{D}, \mathrm{FeQ} 3} & =\left[\mathrm{FeQ}_{3}\right]_{\mathrm{IL}} /\left[\mathrm{FeQ}_{3}\right], \\
K_{\mathrm{D}, \mathrm{FeQ} 2+} & =\left[\mathrm{FeQ}_{2}{ }_{\mathrm{IL}}\left[\mathrm{C}_{\mathrm{n}} \mathrm{mim}^{+}\right] /\left[\mathrm{FeQ}_{2}{ }^{+}\right] .\right.
\end{aligned}
$$

In this case, the products $\beta_{\mathrm{FeQ} 3} K_{\mathrm{D}, \mathrm{FeQ} 3}$ and $\beta_{\mathrm{FeQ} 2+} K_{\mathrm{D}, \mathrm{FeQ} 2+}$ correspond to the equilibrium constants for the following reactions, respectively: 


$$
\begin{aligned}
& \mathrm{Fe}^{3+}+3 \mathrm{Q}^{-} \rightleftharpoons \mathrm{FeQ}_{3 \mathrm{IL}}, \\
& \mathrm{Fe}^{3+}+2 \mathrm{Q}^{-}+\mathrm{C}_{\mathrm{n}} \mathrm{mim}^{+}{ }_{\mathrm{IL}} \rightleftharpoons \mathrm{FeQ}_{2}{ }^{+} \mathrm{IL}+\mathrm{C}_{\mathrm{n}} \mathrm{mim}^{+} .
\end{aligned}
$$

In addition, when using the following apparent distribution constant,

$$
\begin{aligned}
& K_{\mathrm{D}, \mathrm{FeQ} 2+}^{\prime}=\left[\mathrm{FeQ}_{2}{ }^{+}\right]_{\mathrm{IL}} /\left[\mathrm{FeQ}_{2}{ }^{+}\right] \\
& \quad=K_{\mathrm{D}, \mathrm{FeQ} 2+} /\left[\mathrm{C}_{\mathrm{n}} \mathrm{mim}^{+}\right]=K_{\mathrm{D}, \mathrm{FeQ} 2+} K_{\mathrm{SP}^{-1 / 2}},
\end{aligned}
$$

the product $\beta_{\mathrm{FeQ} 2+} K_{\mathrm{D}, \mathrm{FeQ} 2+}^{\prime}$ can be used as the apparent equilibrium constant for Eq. (21).

With consideration for the above-mentioned complicated distribution equilibria for $\mathrm{HQ}$, the extracted $\mathrm{Fe}(\mathrm{III})$ species in the IL chelate extraction system was determined from the relationship between $D$ and $\left[\mathrm{Q}^{-}\right]$. The $\left[\mathrm{Q}^{-}\right]$values were

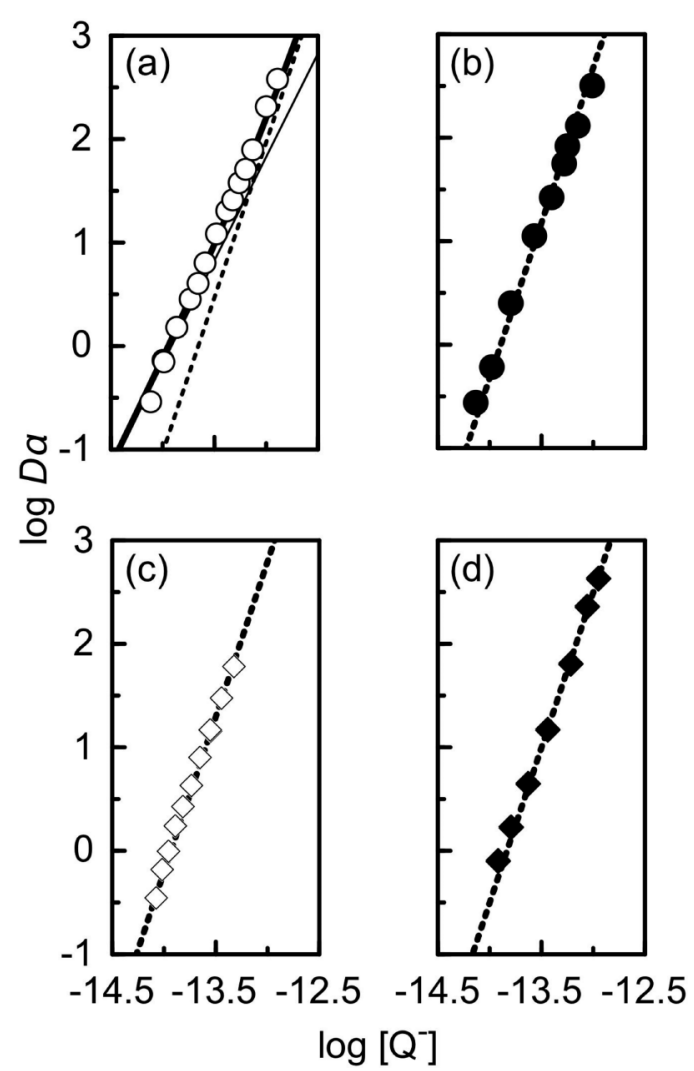

Fig. 3 Plots of $\log D \alpha$ for $\mathrm{Fe}(\mathrm{III})$ as a function of $\log \left[\mathrm{Q}^{-}\right]$. The initial HQ concentration in the extraction phase was $1.0 \times 10^{-2} \mathrm{~mol} \mathrm{dm}^{-3}$. The thick bold curve (a) was obtained by a non-linear least-squares fitting. (The fine solid line and the fine broken line are asymptotic ones with a slope of 2 and 3, respectively.) The thick broken lines $(b-d)$ were obtained by a linear least-squares fitting with a slope of 3 . Extraction phase: (a) $\mathrm{C}_{2} \operatorname{mimTf}_{2} \mathrm{~N}$; (b) $\mathrm{C}_{4} \operatorname{mimTf}_{2} \mathrm{~N}$; (c) $\mathrm{C}_{6} \operatorname{mimTf}_{2} \mathrm{~N}$; (d) $\mathrm{C}_{8} \operatorname{mimTf}{ }_{2} \mathrm{~N}$. calculated using the obtained distribution constants. In this case, possible deviation of $\left[\mathrm{C}_{\mathrm{n}} \mathrm{mim}^{+}\right]$from $K_{\mathrm{SP}}^{1 / 2}$ was estimated as within 5\% (0.02 logarithmic unit). Figure 3 shows relationship between $\log D \alpha$ for $\mathrm{Fe}(\mathrm{III})$ and $\log \left[\mathrm{Q}^{-}\right]$, where the side reaction coefficient $\alpha$ (for hydrolysis of $\mathrm{Fe}(\mathrm{III})$ ) is defined as

$$
\begin{aligned}
\alpha & =\left(\left[\mathrm{Fe}^{3+}\right]+\left[\mathrm{Fe}(\mathrm{OH})^{2+}\right]+\left[\mathrm{Fe}(\mathrm{OH})_{2}^{+}\right]+\left[\mathrm{Fe}(\mathrm{OH})_{3}\right]\right) /\left[\mathrm{Fe}^{3+}\right] \\
& =1+\beta_{\mathrm{Fe}(\mathrm{OH})}\left[\mathrm{OH}^{-}\right]+\beta_{\mathrm{Fe}(\mathrm{OH}) 2}\left[\mathrm{OH}^{-}\right]^{2}+\beta_{\mathrm{Fe}(\mathrm{OH}) 3}\left[\mathrm{OH}^{-}\right]^{3}
\end{aligned}
$$

and the stability constants of hydroxo complexes, $\beta_{\mathrm{Fe}(\mathrm{OH})}, \beta_{\mathrm{Fe}(\mathrm{OH}) 2}$ and $\beta_{\mathrm{Fe}(\mathrm{OH}) 3}$, are $10^{11.81}, 10^{22.2}$ and $10^{30}$, respectively. ${ }^{43}$

When using $\mathrm{C}_{4} \operatorname{mimTf}{ }_{2} \mathrm{~N}, \mathrm{C}_{6} \operatorname{mimTf}_{2} \mathrm{~N}$ and $\mathrm{C}_{8} \operatorname{mimTf} \mathrm{F}_{2} \mathrm{~N}$, the plots showed a straight line with a slope of $c a .3$ (Figs. 3b - 3d). It was subsequently confirmed that $\mathrm{Fe}(\mathrm{III})$ is extracted into these phases as neutral $\mathrm{FeQ}_{3}$ as shown Eq. (20). In these cases, $D \alpha$ is expressed as

$$
\begin{aligned}
& D \alpha=\left[\mathrm{FeQ}_{3}\right]_{\mathrm{IL}} /\left[\mathrm{Fe}^{3+}\right]=\left[\mathrm{Q}^{-}\right]^{3} \beta_{\mathrm{FeQ} 3} K_{\mathrm{D}, \mathrm{FeQ} 3}, \\
& \log D \alpha=\log \left(\left[\mathrm{FeQ}_{3}\right]_{\mathrm{IL}} /\left[\mathrm{Fe}^{3+}\right]\right) \\
& \quad=3 \log \left[\mathrm{Q}^{-}\right]+\log \beta_{\mathrm{FeQ} 3} K_{\mathrm{D}, \mathrm{FeQ} 3} .
\end{aligned}
$$

Also, $\log \beta_{\mathrm{FeQ} 3} K_{\mathrm{D}, \mathrm{FeQ} 3}$ can be obtained with using linear least squares fitting. When using $\mathrm{C}_{2} \operatorname{mimTf}_{2} \mathrm{~N}$, on the contrary, the plot showed a curve having two asymptotic lines with slopes of 2 and 3 (Fig. 3(a)), which suggested that neutral $\mathrm{FeQ}_{3}$ and cationic $\mathrm{FeQ}_{2}{ }^{+}$are competitively extracted into the $\mathrm{C}_{2} \operatorname{mimTf}_{2} \mathrm{~N}$ phase as shown in Eqs. (20) and (21). In this case, $D \alpha$ is shown as

$$
\begin{aligned}
& D \alpha=\left(\left[\mathrm{FeQ}_{3}\right]_{\mathrm{IL}}+\left[\mathrm{FeQ}_{2}\right]_{\mathrm{IL}}\right) /\left[\mathrm{Fe}^{3+}\right] \\
& \quad=\left[\mathrm{Q}^{-}\right]^{3} \beta_{\mathrm{FeQ} 3} K_{\mathrm{D}, \mathrm{FeQ} 3}+\left[\mathrm{Q}^{-}\right]^{2} \beta_{\mathrm{FeQ} 2+} K_{\mathrm{D}, \mathrm{FeQ} 2+},
\end{aligned}
$$

and the two logarithmic constants, $\log \beta_{\mathrm{FeQ} 3} K_{\mathrm{D}, \mathrm{FeQ} 3}$ and $\log \beta_{\mathrm{FeQ} 2+} K_{\mathrm{D}, \mathrm{FeQ} 2+}$ can be calculated with using non-linear least squares fitting to Fig. 3(a). The obtained values of $\log \beta_{\mathrm{FeQ} 3} K_{\mathrm{D}, \mathrm{FeQ} 3}$ and $\log \beta_{\mathrm{FeQ}+} K_{\mathrm{D}, \mathrm{FeQ} 2+}^{\prime}$ and the calculated values of $\log K_{\mathrm{ex}, \mathrm{FeQ} 3}, \log \beta_{\mathrm{FeQ} 2+} K_{\mathrm{D}, \mathrm{FeQ} 2+}$ and $\log K_{\mathrm{ex}, \mathrm{FeQ} 2+}$ are summarized in Table 2.

Although these four IL extraction systems showed obviously different extractability for $\mathrm{Fe}(\mathrm{III})$, the obtained $\log \beta_{\mathrm{FeQ} 3} K_{\mathrm{D}, \mathrm{FeQ} 3}$ and $\log K_{\text {ex,FeQ3 }}$ values are very similar to one another. From these facts, we focused attention on the cation-exchange distribution of protonated $\mathrm{H}_{2} \mathrm{Q}^{+}$into the $\mathrm{IL}$ phase shown as Eq. (5). Namely, a large distribution of $\mathrm{H}_{2} \mathrm{Q}^{+}$is followed by the large decrease in the concentration of $\mathrm{HQ}$ in the IL phase and that of $\mathrm{Q}^{-}$in the aqueous phase. The values of $\left[\mathrm{H}_{2} \mathrm{Q}^{+}\right]_{\mathrm{IL}},[\mathrm{HQ}]_{\mathrm{IL}}$ and $\left[\mathrm{Q}^{-}\right]$at $\mathrm{pH} 2.0$ calculated from the determined equilibrium constants for HQ are given in Table 3 as example. The [HQ] $]_{I L}$ in the $\mathrm{C}_{2} \operatorname{mimTf}_{2} \mathrm{~N}$ system having high $\log K_{\mathrm{D}, \mathrm{H} 2 \mathrm{Q}+}^{\prime}$ was $c a$. 9-fold lower than that in the $\mathrm{C}_{8} \operatorname{mimTf}_{2} \mathrm{~N}$ system having low one, and the $\left[\mathrm{Q}^{-}\right]$was $c a$. 5-fold lower. It was confirmed that the cation-exchange distribution of $\mathrm{H}_{2} \mathrm{Q}^{+}$acts as a competitive sidereaction to control the extraction performance for $\mathrm{Fe}(\mathrm{III})$.

The competitive extraction of cationic $\mathrm{FeQ}_{2}{ }^{+}$was confirmed only concerning the use of less-hydrophobic $\mathrm{C}_{2} \operatorname{mimTf}_{2} \mathrm{~N}$ as the

Table 2 Obtained $\log \beta_{\mathrm{FeQ} 3} K_{\mathrm{D}, \mathrm{FeQ} 3}, \log K_{\mathrm{ex}, \mathrm{Fe} 33}, \log \beta_{\mathrm{FeQ} 2+} K_{\mathrm{D}, \mathrm{FeQ} 2+}^{\prime}, \log \beta_{\mathrm{FeQ} 2+} K_{\mathrm{D}, \mathrm{FeQ} 2+}$ and $\log K_{\mathrm{ex}, \mathrm{FeQ} 2+}$ values

\begin{tabular}{cccccc}
\hline Extraction solvent & $\log \beta_{\mathrm{FeQ} 3} K_{\mathrm{D}, \mathrm{FeQ} 3}$ & $\log K_{\mathrm{ex}, \mathrm{FeQ} 3}$ & $\log \beta_{\mathrm{FeQ} 2+} K_{\mathrm{D}, \mathrm{FeQ} 2+}$ & $\log \beta_{\mathrm{FeQ} 2+} K_{\mathrm{D}, \mathrm{Fe} 2+}$ & $\log K_{\mathrm{ex}, \mathrm{Fe} 2+}$ \\
\hline $\mathrm{C}_{2} \operatorname{mimTf}_{2} \mathrm{~N}$ & $40.97 \pm 0.07$ & 5.47 & $27.83 \pm 0.05$ & 26.50 & 2.83 \\
$\mathrm{C}_{4} \operatorname{mimTf}_{2} \mathrm{~N}$ & $41.68 \pm 0.04$ & 5.74 & - & - & - \\
$\mathrm{C}_{6} \operatorname{mimTf}_{2} \mathrm{~N}$ & $41.84 \pm 0.01$ & 5.56 & - & - & - \\
$\mathrm{C}_{8} \mathrm{mimTf}_{2} \mathrm{~N}$ & $41.54 \pm 0.03$ & 5.25 & - & - \\
\hline
\end{tabular}


Table 3 Calculated values of $\left[\mathrm{H}_{2} \mathrm{Q}^{+}\right]_{\mathrm{L}},[\mathrm{HQ}]_{\mathrm{IL}}$ and $\left[\mathrm{Q}^{-}\right]$at $\mathrm{pH} 2.0$

\begin{tabular}{cccc}
\hline $\begin{array}{c}\text { Extraction } \\
\text { solvent }\end{array}$ & {$\left[\mathrm{H}_{2} \mathrm{Q}^{+}\right]_{\amalg} / \mathrm{mol} \mathrm{dm}^{-3}$} & {$[\mathrm{HQ}]_{\amalg} / \mathrm{mol} \mathrm{dm}^{-3}$} & {$\left[\mathrm{Q}^{-}\right] / \mathrm{mol} \mathrm{dm}^{-3}$} \\
\hline $\mathrm{C}_{2} \operatorname{mimTf}_{2} \mathrm{~N}$ & $8.21 \times 10^{-3}$ & $2.15 \times 10^{-5}$ & $3.16 \times 10^{-15}$ \\
$\mathrm{C}_{4} \operatorname{mimTf}_{2} \mathrm{~N}$ & $5.96 \times 10^{-3}$ & $6.76 \times 10^{-5}$ & $7.08 \times 10^{-15}$ \\
$\mathrm{C}_{6} \operatorname{mimTf}_{2} \mathrm{~N}$ & $2.89 \times 10^{-3}$ & $1.53 \times 10^{-4}$ & $1.24 \times 10^{-14}$ \\
$\mathrm{C}_{8} \operatorname{mimTf}_{2} \mathrm{~N}$ & $9.26 \times 10^{-4}$ & $1.97 \times 10^{-4}$ & $1.58 \times 10^{-14}$ \\
\hline
\end{tabular}

Initial HQ concentration in the IL phase: $1.0 \times 10^{-2} \mathrm{~mol} \mathrm{dm}^{-3}$.

extraction phase. The specific behavior seems to originate in its relatively low extractability for neutral $\mathrm{FeQ}_{3}$, as mentioned above, and in its relatively high ability in cation-exchange extraction based on the low hydrophobicity of $\mathrm{C}_{2} \mathrm{mim}^{+}$. In addition, $\mathrm{FeQ}^{2+}$ is a coordinatively-unsaturated complex and, therefore, is hydrated in the aqueous phase. Namely, it was suggested that coordinatively-unsaturated chelates can be extracted in IL chelate extraction under a suitable condition.

\section{Conclusion}

First, the distribution behavior of HQ between IL and aqueous phases was investigated with using the four ILs having different hydrophobicity. Not only neutral HQ but also cationic $\mathrm{H}_{2} \mathrm{Q}^{+}$ were distributed into the IL phase. A similar distribution behavior for the HQ was shown for all ILs, whereas a different distribution behavior for the $\mathrm{H}_{2} \mathrm{Q}^{+}$based on cation-exchange was observed among the ILs with the order of $\mathrm{C}_{2} \operatorname{mimTf}_{2} \mathrm{~N}>$ $\mathrm{C}_{4} \operatorname{mimTf}_{2} \mathrm{~N}>\mathrm{C}_{6} \operatorname{mimTf}_{2} \mathrm{~N}>\mathrm{C}_{8} \operatorname{mimTf}_{2} \mathrm{~N}$ and the order is same as that in conventional cation-exchange extraction in IL system. In the IL chelate extraction of $\mathrm{Fe}(\mathrm{III})$ with $\mathrm{HQ}$, the extractability order was $\mathrm{C}_{8} \operatorname{mimTf}_{2} \mathrm{~N} \approx \mathrm{C}_{6} \operatorname{mimTf}_{2} \mathrm{~N}>\mathrm{C}_{4} \operatorname{mimTf}_{2} \mathrm{~N}$ $>\mathrm{C}_{2} \operatorname{mimTf}_{2} \mathrm{~N}$. Since the determined equilibrium constants for the extraction as neutral complex $\mathrm{FeQ}_{3}$ were similar among the four extraction systems, it was found that the difference in the $\mathrm{Fe}(\mathrm{III})$-extractability is due to that in distribution of $\mathrm{H}_{2} \mathrm{Q}^{+}$. In the use of $\mathrm{C}_{2} \operatorname{mimTf}_{2} \mathrm{~N}$ having low-hydrophobic $\mathrm{C}_{2} \mathrm{mim}^{+}$, moreover, cationic $\mathrm{FeQ}_{2}{ }^{+}$was competitively extracted. In conclusion, it was found that the distribution of amphoteric extraction reagents can affect its IL chelate extraction performance.

\section{Acknowledgements}

This study was financially supported in part by JSPS KAKENHI Grant No. JP26410162 from the Japan Society for the Promotion of Science.

\section{References}

1. R. D. Rogers and K. R. Seddon, Science, 2003, 302, 792.

2. E. Arkan, Z. Karimi, M. Shamsipur, and R. Saber, Anal. Sci., 2013, 29, 855.

3. Y. Kudo, M. Shibata, S. Nomura, and N. Ogawa, Anal. Sci., 2017, 33, 739 .

4. S. Fujinaga, K. Unesaki, Y. Kawai, K. Kitaguchi, K. Nagatani, M. Hashimoto, K. Tsukagoshi, and J. Mizushima, Anal. Sci., 2014, 30, 1005.

5. S. Fujinaga, M. Hashimoto, K. Tsukagoshi, and J. Mizushima, Anal. Sci., 2016, 32, 455.

6. K. Nagatani, Y. Shihata, T. Matsushita, and K. Tsukagoshi,
Anal. Sci., 2016, 32, 1371.

7. X. Guo, H. Wu, S. Guo, Y. Shi, J. Du, P. Zhu, and L. Du, Anal. Sci., 2016, 32, 763.

8. N. Hirayama, Solvent Extr. Res. Dev., Jpn., 2011, 18, 1.

9. Y. Baba, F. Kubota, N. Kamiya, and M. Goto, J. Chem. Eng. Jpn., 2011, 44, 679.

10. A. Stojanovic and B. K. Keppler, Sep. Sci. Technol., 2012, 47, 189.

11. P. R. Vasudeva Rao, K. A. Venkatesan, A. Rout, T. G. Srinivasan, and K. Nagarajan, Sep. Sci. Technol., 2012, 47, 204.

12. X. Sun, H. Luo, and S. Dai, Chem. Rev., 2012, 112, 2100.

13. Z. Kolarik, Solv. Extr. Ion. Exch., 2013, 31, 24.

14. E. M. Martinis, P. Berton, and R. G. Wuilloud, Trends Anal. Chem., 2014, 60, 54.

15. J. Park, V. Jung, P. Kusumah, J. Lee, K. Kwon, and C. K. Lee, Int. J. Mol. Sci., 2014, 15, 15320.

16. N. Hirayama, Bunseki, 2014, 177.

17. F. Pena-Pereira and J. Namiesnik, ChemSusChem, 2014, 7, 1784.

18. B. Pospiech and W. Kujawski, Rev. Chem. Eng., 2015, 31, 179.

19. C. H. C. Janssen, N. A. Macías-Ruvalcaba, M. AguilarMartínez, and M. N. Kobrak, Int. Rev. Phys. Chem., 2015, 34,591

20. N. Hirayama, M. Deguchi, H. Kawasumi, and T. Honjo, Talanta, 2005, 65, 255.

21. T. Ajioka, S. Oshima, and N. Hirayama, Talanta, 2008, 74, 903.

22. M. J. Muldoon, C. M. Gordon, and I. R. Dunkin, J. Chem., Soc., Perkin Trans. 2, 2001, 433.

23. M. L. Dietz and J. A. Dzielawa, Chem. Commun., 2001, 2124.

24. K. Kidani, N. Hirayama, and H. Imura, Anal. Sci., 2008, 24, 1251.

25. N. Hirayama, H. Okamura, K. Kidani, and H. Imura, Anal. Sci., 2008, 24, 1697.

26. K. Kidani and H. Imura, Talanta, 2010, 83, 299.

27. G.-T. Wei, J.-C. Chen, and Z. Yang, J. Chin. Chem. Soc., 2003, 50, 1123.

28. N. Hirayama, JAERI-Conf, 2004, 2003-021, 103.

29. M. Kumano, T. Yabutani, J. Motonaka, and Y. Mishima, Int. J. Mod. Phys., 2006, 20, 4051.

30. N. Hirayama, Bunseki Kagaku, 2008, 57, 949.

31. T. Takata and N. Hirayama, Anal. Sci., 2009, 25, 1269.

32. H. Abdolmohammad-Zadeh and G. H. Sadeghi, Anal. Chim. Acta, 2009, 649, 211.

33. H. Abdolmohammad-Zadeh and G. H. Sadeghi, Talanta, 2010, 81, 778 .

34. M. Zeeb and M. Sadeghi, Microchim. Acta, 2011, 175, 159.

35. M. Chamsaz, A. Atadori, M. Eftekhari, S. Asadpour, and M. Adibi, J. Adv. Res., 2013, 4, 35.

36. A. H. Panhwar, T. G. Kazi, H. I. Afridi, A. R. Abbasi, M. B. Arain, Naeemullah, S. A. Arain, S. S. Arain, and J. Ali, Anal. Methods, 2014, 6, 8277.

37. M. S. Arain, S. A. Arain, T. G. Kazi, H. I. Afridi, J. Ali, Naeemullah, S. S. Arain, K. D. Brahman, and M. A. Mughal, Spectrochim. Acta, Part A, 2015, 137, 877.

38. S. V. Dzyuba and R. A. Bartsch, ChemPhysChem, 2002, 3, 161.

39. A. K. Burrell, R. E. Del Sesto, S. N. Baker, T. M. McCleskeya, and G. A. Baker, Green Chem., 2007, 9, 449.

40. M. G. Freire, P. J. Carvalho, R. L. Gardas, I. M. Marrucho, L. M. N. B. F. Santos, and J. A. P. Coutinho, J. Phys. Chem. $B, 2008,112,1604$.

41. J. Starý, "The Solvent Extraction of Metal Chelates", 1964, Pergamon Press, New York.

42. T. Hamamoto, M. Okai, and S. Katsuta, J. Phys. Chem. B, 2015, 119, 6317.

43. S. Kotrlý and L. Šu cha, "Handbook of Chemical Equilibria in Analytical Chemistry", 1985, John Wiley and Sons, New York. 